\title{
Structural geological complications for tunnel construction in the Kostenets's section of the Maritsa fault zone in Central Bulgaria
}

\section{Структурно-геоложки усложнения на тунелното строителство в Костенецкия дял на Маришката разломна зона в Централна България}

\author{
Dian Strahilov, Ivan Dimitrov \\ Диан Страхилов, Иван Димитров
}

University of Mining and Geology, Sofia, Bulgaria; E-mail: dian.strahilov@gmail.com, idim68@abv.bg

\begin{abstract}
The structural geological features defining the discontinuity network in metamorphic rocks hosting railway tunnels are described. Discussion on the faults, joints, lineation and stresses found from fault population is presented. It is demonstrated that the formation of some brittle joints is related to the ductile stretching lineation. The geotechnical situation for the tunnel construction is complicated and requires reassessment of the design solutions in order to accommodate substantial lateral forces and prevent shear of the tubes.
\end{abstract}

Keywords: rock mass rating, tunnels, faults, joints, lineation, stress.

\section{Introduction}

The work is devoted to a 6.3 kilometers long section of the fast railway Kostenets-Septemvry, which encompass three projected tunnels and two bridges between them. All of them are along the Maritsa valley southeast of Kostenets. The railway tracks follow and intersect the Maritsa valley, which in the southern part of the studied segment have a bearing of approximately $300 \mathrm{NW}$ but in the northern part the bearing is from 355 to $335 \mathrm{NW}$ (Fig. 1a). This requires the railway tracks to follow the significant WNW striking faults along the valley, cross them and run across numerous fault structures of various rang (Dimitrova, Katskov, 1990) that might be related to the Maritsa fault zone (MFZ). The MFZ is studded and discussed in numerous works (e.g. Naydenov et al. 2013) however some researchers admit that the pre-tertiary evolution of these fault zone is better known than the tertiary one and that "there are no indications for current activity of the strike-slip fault system" (Gerdjikov, Georgiev, 2006). The resent works exposing results from GNSS measurements (Dimitrov, Nakov, 2020, 2021) imply for consistent N-S mass transport, which is nearly at right angle to the MFZ.

The work presented here is a site-specific study of the interplay of various structural geological features examined in the context of an engineering geological project on a very detailed scale. The purpose of the project was entirely pragmatic and related to the tun- nel construction. In doing this study, a rather striking structural interplay between brittle and ductile deformations was revealed, which is rarely described in the specialized literature. This interplay directly affects the engineering properties of the rocks in this particular segment of the railway and should be taken into account in the design solutions of the tunnels.

\section{Method and purpose of the study}

The method of the study is primarily structural mapping and stereographic statistical analysis of observed structural features. The structural observations were made on the outcrops along the road connecting Kostenets and Momina Klisura. Faults, joints and ductile deformation features such as stretching lineation and minor fold axes were measures together with metamorphic foliation and lithological layering, where possible. Not all lithological varieties were found on the field, because some varieties are thin compared to the spacing of the exposures but the main lithologies are sufficiently correctly identified.

Additional information was gathered from the drills, during the technical report stage of the engineering geological study of the tunnel and bridge sites. Drilling indeed revealed significant faults under the alluvium of the flooded river terrace. The kinematic significance of the measured faults was analysed (Marrett, Allmendinger, 1990) and principal stress orientation of tectonic origin was found for the 
structurally uniform domains using FaultKin 8.0 software. The FaultKin software analyses strain from fault populations that contain measurable striations or other indication for the displacement direction.

The purpose of this study is to select and apply appropriate rocks mas rating system using critical analysis of its applicability in the site-specific sense (Rehman et al., 2018; Dimitrov, 2020). Additional purpose is to provide data for slip analysis of the planes of weakness in the tunnels (Bott, 1959; Dimitrov, 2018). The rock mass rating will be elaborated in near future but some structural geological features of general scientific significance can be reported in advance, so they are presented in this paper.

\section{Brittle to brittle ductile structural features}

Joints. The density of the joints varies according to the lithology type and the location of the study domain with respect to the foliation and the major faults. All rocks in the study domains are intensely jointed as the spacing of the joints vary from around $10 \mathrm{~cm}$ to nearly complete brecciation of millimetre scale. At some localities, especially, where marbles are exposed, fine network of discontinuous expose an elephant skin textures of the rock, which is semi coherent, because of low temperature annealing. In the gneisses the dense joints separate elongated fragments, which are parallel to the ductile flow direction. In general north-south and east-west striking joints are observed but because the foliation tends to accommodate shearing the joints are more pronounced, where they intersect the foliated rocks at a high angle. On Figure 1 ( $b$ and $c$ insets) long and smooths joint planes are shown, which form kinematically unstable rocks wedges.
Faults. Close to 70 small to medium displacement fault planes were measured with complete recording of the striation on them. The faults group into to maximums striking N-S an E-W. It is noteworthy to mention that in the northern domain, the lithology controls the small fault orientation, so because it is striking to E-W and dipping to south the majority of the fault are $\mathrm{N}-\mathrm{S}$ striking. In the southern domain more various fault orientation are present.

\section{Ductile structural features}

Small folds. Small fold transposed in the foliation were measures in the northern and in the southern domain. In the northern domain (tunnel 11) their hinges are plunging approximately $280 / 50$ but in the southern domain they are nearly horizontal (for tunnel 12) to shallowly dipping (for tunnel 13). Extensional jointing perpendicular to the hinges is common in all exposures. Striation parallel to the hinges indicate hinge parallel displacement.

Mineral fiber lineation. This type of lineation was not observed in the marbles and calcareous schists but is common in the gneisses of the southern domain. Around tunnel 12 (Fig. 1c) it is a typical stretching lineation with subordinated extensional brittle joints perpendicular to it. They apparently form, when the ductile limit of strength is surpassed in the rocks. This lineation strike to $280-290 \mathrm{~W}$ or $100-110 \mathrm{E}$ and is kinematically coherent with the major displacement direction along the Maritsa fault zone. The difference in the plunges of this lineation can be explained with the fact that secondary faults are formed to north and south of the main fault zone and they rotate the rock domain between them. These faults are NE and NW striking. Such fault

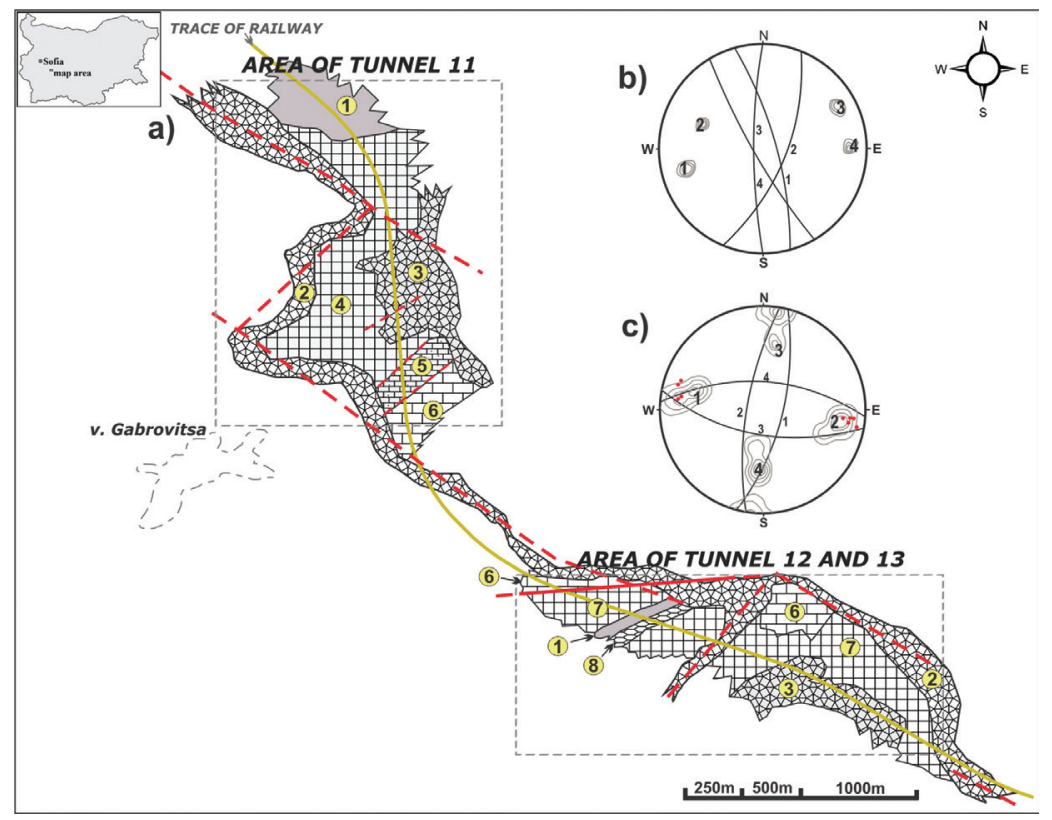

Fig. 1. $a$, geology sketch of the research area: 1, green schists (diabases, metatuffs, metaporphyry); 2, young alluvium - modern river terrace; 3, old alluvium - higher river terrace; 4, amphibole-biotite gneisses; 5, marble-gneiss alternation; 6 , thick-bedded (massive) marbles; 7 , two-micas gneisses; 8 , biotite schists (almost monomineral); $b$, stereogram representing 4 joint maximums received form 66 joint planes, measured in the area of the tunnel 11; $c$, stereogram representing 4 joint maximums received form 65 joint planes, measured in area of tunnels 12 and 13 and mineral stretching lineation marked with red points 
was inferred in the valley of Kriva river, between the portal area of tunnel 12 and tunnel 13. In addition to the oblique faulting a thrusting event is inferred for this area, which is superimposed on the complex strike-slip environment of the Maritsa fault zone.

\section{Brittle-ductile structure interplay}

The most striking feature of this structural environment is the relationship between the stretching lineation and the brittle joints. As it can be seen from figure 1c the E-W striking joints intersect in the directions of the lineation. It is shown on the stereogram that the lineation direction appears as common axes if rotation for the joint planes. That is the joints intersect in a line, which is parallel to the lineation. This is in no way coincidence. In addition, the N-S striking joints form as extensional features perpendicular to the lineation. This strongly suggests for dependence between the lineation and the joints and fortifies the conclusion for displacement in the lineation direction. The lineation parallel joint planes separate very pronounced linear fragments, which is observed in the plane of the perpendicular joints as a brecciated texture of the gneisses. In tunnel 12 and 13 the elongation of the fragments is roughly parallel to the axes of the tunnel. Thus, apparent displacement in the main direction of the Marisa zone created both ductile stretching lineation and brittle intersection lineation.

\section{Tectonic stress orientations}

All faults indicate for near vertical $\sigma 2$ and near horizontal $\sigma 1$. In other words, tectonic events that happened in the past in this region were created by a strike-slip fault kinematics, which suggests that the future events might be strike-slip too.

The interpretation of the faults and joints suggests that the N-S trending faults are subordinated to the W-E trending ones and are mostly reactivated joints. Thus, the main mass movement in the geological past is supposed to be towards WNW. If the faults are sorted by groups and the eigenvalues calculated for each group separately, the WNW-ESE trending ones appear exactly strike-slip and the N-S trending ones are of mixed kinematics - normal and strike-slip. It is very plausible to assume that the N-S faults are contemporary to the present north-southern flow of crustal material demonstrated by Dimitrov and Nakov $(2020,2021)$.

\section{Conclusions}

The structural features along the railway indicate for the most complex alpine style condition of tunnel building (EC report, 2018). Very obviously, the tunnels will be built in rocks that suffered multiple faulting events. The tectonic brecciation, jointing and fault slip are crosscutting as well as longitudinal to the tunnels, so measures have to be taken to prevent displacements of the tubes.

The stress analysis performed on striated faults indicates that the expected maximal tectonic action on the tubes will be nearly horizontal. This emphasizes that the tectonics will have more influence on the tun- nels than the gravity. The overburden should not be taken as a definitive factor for the safety, because the discontinuity network of fractures and foliation can transmit much larger seismic force not from above but sideways to the tubes. This is important because the studied area is in the vicinity of the Maritsa fault zone, which has notable seismicity (Shanov, 1998; Protopopova, Botev, 2014).

Because strong jointing in foliated rocks is the main discontinuity to be accounted for, the RMR rating is not appropriate for these rocks, because it is designed for rather isotropic rocks and doesn't have enough provisions for joint feature. Likely the most appropriate rating can be done by Burton's Norwegian rating or Qscheme, because they are developed for gneisses and shists and have more provisions for jointing and shears.

Acknowledgements: This work is supported by DZZD "Kostenets - Septemvry 2018".

\section{References}

Bott, M. H. P. 1959. The mechanics of oblique slip faulting. Geol. Mag., 96, 109-117.

EC report. 2018. Assessment of Unit Costs (Standard Prices) of Rail Projects (CAPital EXpenditure). Annex 13 - Case study on tunnels. European Commission, $31 \mathrm{p}$.

Dimitrova, R., N. Katskov. 1990. Geological Map of PR Bulgaria on Scale 1:100000. Velingrad Map Sheet. Sofia, Geology and Mineral Resources Committee, Enterprise of Geophysical Survey and Geological Mapping (in Bulgarian).

Dimitrov, I. 2018. Finding of the maximum shear stress on arbitrary oriented rock discontinuity in the context of the geotechnical practice of road and tunnel construction. - Rev. Bulg. Geol. Soc., 79, 1-2, 59-68 (in Bulgarian with English abstract).

Dimitrov, I. 2020. Structural geological methods in the geotechnical practice - rock mass rating. Advantages and problems of the rating methods. - Rev. Bulg. Geol. Soc., 81, 1, 35-54 (in Bulgarian with English abstract).

Dimitrov, N., R. Nakov. 2020. Recent GPS results on the geodynamics of the area around Sofia (Central Western Bulgaria). - Rev. Bulg. Geol. Soc., 81, 3, 241-243.

Dimitrov, N., R. Nakov. 2021. Supplementary measurements in the Sofia Geodynamic Network. Significance for contemporary local and regional geodynamics. - Rev. Bulg. Geol. Soc., 82, 3, 239-241; https://doi.org/10.52215/rev. bgs.2021.82.3.239.

Gerdjikov, I., N. Georgiev. 2006. The Maritsa fault system strike-slip zone along the northern margin of the Rhodopes. - Ann. Univ Mining and Geol. "St. Ivan Rilski", 49, I-Geol. and Geophys., 33-39 (in Bulgarian with English abstract).

Goodman, R. E. 1976. Methods of Geological Engineering in Discontinuous Rocks. San Francisco, West Publishing, 472 p.

Marrett, R. A., R. W. Allmendinger. 1990. Kinematic analysis of fault-slip data. - J. Structural Geol., 12, 973-986.

Naydenov, K., I. Peytcheva, A. von Quadt, S. Sarov, K. Kolcheva, D. Dimov. 2013. The Maritsa strike-slip shear zone between Kostenets and Krichim towns, South Bulgaria Structural, petrographic and isotope geochronology study. - Tectonophys., 595-596(6), 69-89.

Protopopova, V., E. Botev, I. Georgiev 2014. Focal mechanisms of some earthquakes in the western part of Maritza seismic zone. - Proc. Papers of Sci. Confer. Geography and Regional Sci. Pazardzhik, Bulgaria, 30-31, October 2014, 202-205 (in Bulgarian with English abstract).

Shanov, S. 1998. Seismotectonic model of Maritsa seismic region. - Proc. Symposium "Geodynamic Studies Related to the Chirpan-Plovdiv 1928 Earthquakes”. Sofia, October 9, 1998, 101-112 (in Bulgarian with English abstract). 